\title{
Compressive mechanical properties of atherosclerotic plaques-Indentation test to characterise the local anisotropic behaviour
}

\author{
Chen-Ket Chai ${ }^{a, *, 1}$, Lambert Speelman ${ }^{\text {b,1 }}$, Cees W.J. Oomens ${ }^{a}$, Frank P.T. Baaijens ${ }^{\text {a }}$ \\ a Department of Biomedical Engineering, Eindhoven University of Technology, Eindhoven, The Netherlands \\ ${ }^{\mathrm{b}}$ Department of Biomedical Engineering, Thoraxcentre, Erasmus Medical Centre, Rotterdam, The Netherlands
}

\section{A R T I C L E I N F O}

\section{Article history:}

Accepted 13 January 2014

\section{Keywords:}

Atherosclerosis

Compressive properties

Plaque rupture

Indentation

Finite element method

\begin{abstract}
A B S T R A C T
Accurate material models and associated parameters of atherosclerotic plaques are crucial for reliable biomechanical plaque prediction models. These biomechanical models have the potential to increase our understanding of plaque progression and failure, possibly improving risk assessment of plaque rupture, which is the main cause of ischaemic strokes and myocardial infarction. However, experimental biomechanical data on atherosclerotic plaque tissue is scarce and shows a high variability. In addition, most of the biomechanical models assume isotropic behaviour of plaque tissue, which is a general oversimplification. This review discusses the past and the current literature that focus on mechanical properties of plaque derived from compression experiments, using unconfined compression, microindentation or nano-indentation. Results will be discussed and the techniques will be mutually compared. Thereafter, an in-house developed indentation method combined with an inverse finite element method is introduced, allowing analysis of the local anisotropic mechanical properties of atherosclerotic plaques. The advantages and limitations of this method will be evaluated and compared to other methods reported in literature.
\end{abstract}

(c) 2014 Elsevier Ltd. All rights reserved.

\section{Introduction}

Atherosclerosis is a disorder of the arterial wall. The vessel wall is invaded by lipids and inflammatory cells that can eventually lead to formation of an atherosclerotic plaque. Some of these plaques develop into plaques that are vulnerable for plaque rupture. Such a vulnerable plaque consists of inflammatory cells, a lipid rich necrotic core, intra-plaque haemorrhage, and a thin fibrous cap separating the thrombogenic lipid core from the bloodstream (Schaar et al., 2004; Stary et al., 1992). In case of rupture of the thin fibrous cap, the lipid core comes into contact with the blood, causing luminal thrombus formation. This thrombus may cause a blockage in the vessels distal to the plaque. This is the major cause of ischaemic stroke and myocardial infarction (Sakakura et al., 2013).

Current methods to assess plaque rupture risk are mostly based on general risk factors (age, hypertension, and familial arterial diseases), and on geometrical plaque features (stenosis degree,

\footnotetext{
* Correspondence to: Eindhoven University of Technology, Department of Biomedical Engineering, PO Box 513, GEM-Z 4.11, 5600 MB Eindhoven,

The Netherlands. Tel.: +31 40247 3047; fax: + 31402447355 .

E-mail address: C.Chai@tue.nl (C.-K. Chai).

1 These authors contributed equally to this work.
}

intima-media thickness, and irregular, ulcerated plaque morphology) (Naghavi, 2010). It has been shown that these risk factors are insufficient for predicting future plaque rupture events. A reliable computational model to predict cap rupture may, therefore, add to the diagnosis and treatment of atherosclerotic plaques. Since fibrous cap rupture occurs when the stresses in the cap exceed the strength of the cap, biomechanical plaque modelling has the potential to improve risk assessment of plaque rupture (Sadat et al., 2011; Salunke and Topoleski, 1997). Biomechanical plaque studies have revealed that patient-specific plaque models can accurately predict local stress peaks and rupture locations (Akyildiz et al., 2011, this issue; Gillard, 2007; Loree et al., 1992, 1994; Nieuwstadt et al., in press; Speelman et al., 2011; Tang et al., 2005, 2009). However, the stress results from these biomechanical models strongly depend on the material models and the parameters used (Akyildiz et al., 2011; Williamson et al., 2003). Determining the mechanical behaviour of the different plaque components is, therefore, a necessity.

Mechanical characterisation of plaque tissue is frequently done using (uni-)axial tensile tests (Lawlor et al., 2011; Maher et al., 2009), which is discussed by Walsh et al. (this issue) in this special issue. Although plaque tissue in vivo experiences circumferential stretching during blood pressure pulsation, the tissue is also radially compressed during this pulsation. Therefore, also compression tests are 
physiologically relevant to determine the mechanical behaviour of plaque tissue.

The aim of this review paper is to give an overview of the methods used in literature to measure mechanical properties of atherosclerotic plaque tissue using compression experiments. In literature, studies were identified in which the compressive properties of human, porcine or murine plaques were tested, harvested from the aorta, iliac, femoral, or carotid arteries. Plaque tissue was tested using unconfined compression, micro-indentation, or nano-indentation. The results from the different studies and testing techniques will be compared. The advantages and disadvantages of each technique will be discussed. In case the stiffness data was presented non-conventionally, representative figures from the papers were digitised and used to fit a neoHookean material model and to extract tangential stiffness values.

After a summary of the literature on compressive plaque properties, an in-house developed micro-indentation test will be presented for the characterisation of anisotropic properties of plaque tissue. The relevance and limitations of this method will be discussed.

\section{Compressive properties of plaque tissue}

\subsection{Unconfined compression}

Unconfined compression tests are one of the most popular methods to determine mechanical behaviour of materials. The samples are mounted between two metal plates, of which the top plate is stationary and attached to a load measuring device. Generally, during unconfined compression, the tested tissue is smaller in size than the compression plates. The bottom plate can be raised and lowered with a pre-set speed to pre-set positions. Both displacement and force can be used as loading conditions. With unconfined compression tests, compressive mechanical plaque properties can be determined at large, physiologically relevant strain. It is a relatively straightforward test that allows both static and dynamic loading conditions. Using static loading conditions, material stiffness can be determined, while frequency-dependent dynamic characteristics can be identified using cyclic unconfined compression loading conditions at different frequencies.

\subsubsection{Human aortic plaques}

Lee et al. (1991) evaluated radial compressive plaque properties, by compressing 27 fibrous caps from 14 abdominal aorta plaques using a $7 \mathrm{~mm}$ diameter cylindrical steel plate. Caps were classified as cellular $(n=7)$, hypo-cellular $(n=9)$, or calcified $(n=11)$ based on histological examination. The tests were conducted at room temperature within $16 \mathrm{~h}$ of patient death. The dynamic stiffness of the test samples (thickness $1.1 \pm 0.2 \mathrm{~mm}$ ) was evaluated by applying a static compressive stress of $9.3 \mathrm{kPa}$ in the radial direction first and, after a resting period to reach static equilibrium, a dynamic stress with an amplitude of $0.5 \mathrm{kPa}$ at different frequencies afterwards. Stiffness values increased with increasing frequency; however, the change was less than $10 \%$ between 0.5 and $2 \mathrm{~Hz}$. As the stiffness was determined at a fixed load, the samples were subjected to different compression levels ( $17 \pm 6 \%$ for cellular, $7 \pm 1 \%$ for hypo-cellular, and $1.2 \pm 0.2 \%$ for calcified samples). The dynamic stiffness was $510 \pm 220 \mathrm{kPa}$ for cellular, $900 \pm 220 \mathrm{kPa}$ for hypo-cellular and $2.2 \pm 1.0 \mathrm{MPa}$ for calcified samples.

The same group studied the relation between compressive mechanical properties and intravascular ultrasound classification of aortic plaques, with a static measurement protocol, using the same set-up (Lee et al., 1992). An initial compressive stress of $4.0 \mathrm{kPa}$ was applied until a static equilibrium was reached.
Thereafter, the compressive stress was increased up to $12 \mathrm{kPa}$. Strain and creep-times were recorded for this step and a stiffness modulus was determined. The compression strain was $24 \pm 11 \%$ for non-fibrous caps, $11 \pm 5 \%$ for fibrous caps and $3 \pm 2 \%$ for calcified caps. Creep times varied from 20 min for calcified samples, $50 \mathrm{~min}$ for fibrous samples, and $80 \mathrm{~min}$ for non-fibrous samples. Nonfibrous samples had a stiffness modulus of $41 \pm 18 \mathrm{kPa}$. The stiffness modulus for fibrous and calcified caps was $82 \pm 33 \mathrm{kPa}$ and $355 \pm 245 \mathrm{kPa}$, respectively.

Although the static loading stress was not equal in both studies (9.3 $\mathrm{kPa}$ versus $8 \mathrm{kPa}$ ), the strain levels were comparable for the plaque samples. However, the reported static stiffness values were about one order lower compared to the reported dynamic stiffness values. Lee et al. (1992) suggested that these differences may be attributed to the non-elastic mechanical behaviour of the tissue, as a different loading stress was applied in both studies $(9.3 \pm 0.5 \mathrm{kPa}$ versus $8 \mathrm{kPa}$ ). Additionally, visco-elastic behaviour of the cap may play a role in the dynamic stiffness results. This is supported by the relatively long creep-times, which were reported by Lee et al. (1992).

Walraevens et al. (2008) used unconfined compression to test the compressive mechanical properties of atherosclerotic calcified human aortas $(n=19)$, obtained from aneurysm repair surgeries. The aortas were cut into $10 \mathrm{~mm} \times 10 \mathrm{~mm}$ strips, with an average thickness of $1.84 \pm 0.28 \mathrm{~mm}$. The aortas were tested at room temperature using an impermeable pounder with a diameter of $6 \mathrm{~mm}$. The $E$-moduli obtained at $10 \%$ strain were $321 \pm 258 \mathrm{kPa}$ for calcified human plaques, which was similar to the calcified samples from Lee et al. (1992), although the amount of compression was different (10\% versus $3 \pm 2 \%$ ).

\subsubsection{Human iliac and femoral plaques}

Topoleski et al. (1997) investigated radial compressive behaviour of aortoiliac plaques by quasi-static compressing samples at $37{ }^{\circ} \mathrm{C}$ using parallel flat acrylic fixtures $(6.35 \mathrm{~mm}$ in radius) (Topoleski et al., 1997; Topoleski and Salunke, 2000). Non-ulcerated lesions $(n=24)$ were obtained from 6 autopsies and stripped from the remaining vessel wall. The samples $(5 \mathrm{~mm} \times 5 \mathrm{~mm}, 2.4 \pm 0.7 \mathrm{~mm}$ thickness) underwent two 15-cycle loading phases up to $350 \mathrm{kPa}$ with a 10-15 min unloaded rest period in between. Three types of plaques were identified based on histological features, which all showed a distinct mechanical behaviour in terms of repeatability and recoverability. The maximum compressive strain at $350 \mathrm{kPa}$ loading stress was $70 \pm 11 \%$ for atheromatous samples, $54 \pm 9 \%$ for fibrous samples, and $14 \pm 9 \%$ for calcified samples. Tangential stiffness values were extracted from the representative curves. Atheromatous samples showed the most compliant response (stiffness $<10 \mathrm{kPa}$ for compression values up to $25 \%$ ). Fibrous samples were stiffer; however, much softer than calcified samples ( $<10 \mathrm{kPa}$ versus $830 \mathrm{kPa}$ at $5 \%$ compression and $85 \mathrm{kPa}$ versus $13 \mathrm{MPa}$ at 20\% compression).

Using the same approach, Salunke et al. (2001) investigated the compressive stress-relaxation behaviour of aortoiliac plaques in radial direction. Atherosclerotic plaques ( 5 calcified, 7 fibrous, and 6 atheromatous samples) were obtained post-mortem. After two 15-cycle preconditioning phases, the samples $(5 \mathrm{~mm} \times 5 \mathrm{~mm}$, $1.5 \pm 0.7 \mathrm{~mm}$ thickness) were subjected to three stress-relaxation phases, with $25 \%$ compression within $1 \mathrm{~s}$ between $16 \mathrm{~mm}$ diameter parallel plates. Stiffness values were determined from representative curves. Fibrous plaques and calcified plaques showed similar stiffness values (100 kPa versus $70 \mathrm{kPa}$ at $5 \%$ compression and 900 versus $1000 \mathrm{kPa}$ at 20\% compression), while atheromatous tissue had a lower average stiffness ( $25 \mathrm{kPa}$ at $5 \%$ compression and $100 \mathrm{kPa}$ at $20 \%$ compression). Compared to Topoleski et al. (1997), the dynamic stiffness of fibrous and atheromatous plaque tissue was higher than the static stiffness, 
while calcified tissue had a lower dynamic stiffness. The nonelastic behaviour of the plaque tissue may have caused differences between quasi-static and dynamic experiments. This is supported by the differences found in relaxation behaviour for the various plaques types. Although none of the plaques were completely recovered after $10 \mathrm{~min}$, atheromatous plaques clearly showed a different response compared to fibrous and calcified samples.

\subsubsection{Human carotid plaques}

Maher et al. (2009) performed unconfined compression tests in radial direction on carotid artery plaque sections $(4 \mathrm{~mm}$ in diameter). Plaque samples ( $n=44$ from 11 patients) were classified as calcified $(n=16)$, echolucent $(n=5)$, and mixed $(n=23)$ based on ultrasound imaging and were loaded up to $60 \%$ compression with a rate of $1 \%$ per second. Significant variation was found in the compressive behaviour between and within patients. Calcified samples showed the stiffest response with an average tangential stiffness of $140 \mathrm{kPa}$ at $5 \%$ compression and $2300 \mathrm{kPa}$ at $20 \%$ compression. The echolucent and mixed samples showed softer average stiffness with 20 and $20 \mathrm{kPa}$ at 5\% compression and 100 and $330 \mathrm{kPa}$ at $20 \%$ compression, respectively.

The same group evaluated the inelastic behaviour of carotid plaques using dynamic cyclic compressive tests at room temperature (Maher et al., 2011). Tests were conducted using 21 samples from 8 patients. Also here ultrasound was used to classify the samples as calcified $(n=8)$, echolucent $(n=5)$, and mixed $(n=8)$. The samples were loaded and unloaded at a rate of $5 \%$ per second, with 5 consecutive loading cycles at levels of $10 \%, 20 \%, 30 \%, 40 \%$, and 50\% strain. Corresponding to Maher et al. (2009), the calcified plaques were on average the stiffest plaque type (2.7 MPa at 50\% compression) while the echolucent plaques were the softest (1.4 MPa at 50\% compression). The mixed samples showed an intermediate stiffness (2.1 $\mathrm{MPa}$ at $50 \%$ compression). For all plaque samples, permanent deformation was observed, which increased with the applied strain level. The magnitude of the permanent deformations occurring during unloading of the plaque was similar for all plaque types.

\subsection{Micro-indentation}

Micro-indentation tests can be used for measuring more local material stiffness of relatively small and inhomogeneous material. The indenters used in micro-indentation testing systems are relatively small compared to the tested tissue. Due to the shape of the indenter and variation in tissue thickness, tissue stiffness cannot be directly derived from the force-depth curves. Numerical simulations are necessary to extract the mechanical properties from the force-depth curves using an inverse approach. The experimental curves are fitted to the curves of the numerical simulation of the indentation to determine the tissue stiffness.

\subsubsection{Human carotid plaques}

Barrett et al. (2009) measured mechanical properties of carotid atherosclerotic plaque caps using a micro-indentation device. A spherical indenter with a diameter of $1 \mathrm{~mm}$ was used to study the quasi-static radial compressive properties of fibrous caps (thickness $0.25-0.75 \mathrm{~mm}$ ) dissected from carotid artery plaques, within $3 \mathrm{~h}$ after surgery. Indentations were carried out until either a force of $0.2 \mathrm{~N}$ was reached, or when an indentation depth of $0.5 \mathrm{~mm}$ was exceeded. Tangential stiffness values were determined with an inverse finite element model and ranged from 21 to $300 \mathrm{kPa}$ (median of $33 \mathrm{kPa}$ at $5-20 \%$ compression).

In a recent study, the local mechanical properties of carotid atherosclerotic plaque tissue were characterised in the axial direction (Chai et al., 2013). Micro-indentations were performed with a $2 \mathrm{~mm}$ diameter spherical indenter on 8 human carotid plaques on $200 \mu \mathrm{m}$ thick axial cross-sections. The plaques were snap-frozen directly after carotid endarterectomy and stored at $-80^{\circ} \mathrm{C}$ until further processing. In total, 214 locations were tested in the middle of the fibrous cap $(n=43)$, shoulder of the cap $(n=61)$, intima $(n=90)$, or lipid rich necrotic core $(n=20)$. Using an inverted confocal microscope, local collagen architecture was determined for all locations. The obtained force-response of up to $30 \%$ indentation was fitted to simulated data generated from a computational finite element model. Isotropic neo-Hookean behaviour and homogeneity of the tested plaque tissue were assumed. The obtained Young's moduli ranged from $6 \mathrm{kPa}$ to $891 \mathrm{kPa}$ (median of $30 \mathrm{kPa}$ ) at $30 \%$ compression, which was similar to the data obtained by Barrett et al. (2009). Due to considerable variation per location, no significant differences could be identified between the middle of the fibrous cap, the shoulder cap regions, and the intima locations. Also, no significant differences were found between the Young's moduli of structured and unstructured collagen architectures. This suggests that for the entire diseased intima the axial compressive mechanical properties can be modelled as homogenous, although the large variation indicates that measurement uncertainties need to be taken into account in further analyses.

\subsection{Nano-indentation}

Even within the different plaque components the tissue is highly heterogeneous, which means that even micro-indentation might be insufficient to detect local difference in mechanical properties. To address this issue, nano-indentation can be applied. One possible method to apply nano-indentation is the use of an atomic force microscope (AFM). It is a very high resolution type of scanning probe microscope that can be used to measure how much force is required to push the micrometre indenter into the tissue. AFM is generally used to scan a tissue surface to produce images that reflect the forces that are experienced by the indenter. Additionally, it can be used to perform very local force-indentation measurements, to obtain the mechanical characteristics of the tissue. Generally, only very small displacements can be applied using this technique.

\subsubsection{Human carotid plaques}

Ebenstein et al. (2009) tested fresh $(n=5)$ and frozen $(n=5)$ human carotid plaques using nano-indentation. The tissue was classified based on Fourier transform infrared (FTIR) spectroscopy to distinguish different plaque components. The plaque components were indented using a conospherical diamond probe tip with a diameter of $200 \mu \mathrm{m}$. The applied peak loads were between 10 to $600 \mu \mathrm{N}$, with a maximum indentation depth of $5 \mu \mathrm{m}$. In total 377 indentations were performed, 34 at haematoma, 172 at fibrous, 72 at partially calcified, and 99 at calcified locations. The resulting Young's moduli for the samples were $230 \pm 210 \mathrm{kPa}$ for haematoma, $270 \pm 150 \mathrm{kPa}$ for fibrous tissue, $2.1 \pm 5.4 \mathrm{MPa}$ for partially calcified fibrous tissue, and $0.7 \pm 2.3 \mathrm{GPa}$ for calcified tissue. Due to the limited indentation depth only properties at the low strain region were obtained, without capturing the non-linear material behaviour at higher strains. There was no significant difference between frozen and fresh plaques, suggesting that freezing the tissue at $-20^{\circ} \mathrm{C}$ does not change the mechanical properties.

Besides human atherosclerotic tissue, also murine aortic plaques were tested using an AFM to characterise mechanical plaque properties (Hayenga et al., 2011; Tracqui et al., 2011). Tracqui et al. (2011) differentiated between cellular fibrotic (mean Young's modulus of $10 \pm 6 \mathrm{kPa}$ ), hypo-cellular fibrous cap (mean Young's modulus of $59 \pm 47 \mathrm{kPa}$ ), and lipid rich regions (mean Young's 
modulus of $6 \pm 4 \mathrm{kPa}$ ), based on histology. The results from Tracqui et al. (2011) and Hayenga et al. (2011) were very similar; however, it is unclear how stiffness results of murine plaques translate to stiffness data of human plaques. However, nano-indentation may prove to be a useful tool for mechanical characterisation of thin caps of human atherosclerotic plaques.

\subsection{Discussion of the compression techniques}

Different techniques to measure the compressive mechanical properties of plaque tissue have been reviewed. Advantages and disadvantages of each technique were discussed in this paper. Depending on the application of the obtained results, one should use the appropriate technique.

Unconfined compression is a widely available method, which can be used for static and dynamic testing, providing global stiffness and relaxation data. As plaque tissue is generally highly heterogeneous, the use of large indenter plates does not allow a very accurate classification of the tested tissue. Therefore, only global tissue classifications (non-fibrous, fibrous, or calcified) are possible, resulting in a large variation in reported mechanical properties within each classification group. As pointed out by Ebenstein et al. (2009), even for the single classification 'calcified plaque', there are different gradations of calcification, depending on the degree of mineralisation of the tissue. This might explain why overlap is often found in the mechanical properties of fibrous and calcified testing locations.

Micro-indentation techniques combine physiologically relevant strains with indenters with an appropriate size to perform local measurements and, therefore, seem to be a good candidate for determining local mechanical properties of atherosclerotic plaque tissue. Besides dedicated hardware, this method requires an inverse finite element analysis to reconstruct stiffness data from the measured force-indentation depth data. To achieve the most reproducible and accurate results with micro-indentation, the tested material under the indenter should be homogeneous. In Chai et al. (2013), the plaque tissue was cut into $200 \mu \mathrm{m}$ thin slices to obtain sections as homogeneous as possible in thickness. However, since cutting the plaque tissue disrupts the local collagen fibres, which play an important role as the load-bearing structures of tissue, the resulting mechanical properties may be affected by this approach. Since plaque tissue is very heterogeneous, local measurements are relevant and testing locations away from tissue edges or damaged locations might have only a minimal influence. Barrett et al. (2009) isolated atherosclerotic plaque caps from the underlying tissue, which is a difficult and laborious procedure and likely produces a bias towards thicker fibrous caps. The caps tested by Barrett et al. (2009) were between 250 and $750 \mu \mathrm{m}$ thick. Kolodgie et al. (2001) concluded that for coronary arteries unstable plaques show fibrous cap thicknesses of $<65 \mu \mathrm{m}$. Redgrave et al. (2008) found that the critical cap thickness for carotid arteries was $<200 \mu \mathrm{m}$. Besides the fact that handling of these thin caps may be very challenging, the spherical micro-indenters with diameters of $1 \mathrm{~mm}$ or $2 \mathrm{~mm}$ are likely to be too large for these caps.

Nano-indentation enables stiffness characterisation of individual collagen fibres and cells, but generally at small strains. Reconstructing the measured data from nano-indentation into mechanical stiffness data is quite complex, as advanced contact algorithms are required due to the small size of the indenter. Extrapolating nano-indentation results to a more macroscopic plaque component material behaviour for biomechanical modelling is not trivial, as also volume fractions and interactions between components need to be known. Nevertheless, nanoindentation may provide valuable data for multi-scale biomechanical modelling. Moreover, nano-indentation might be more appropriate for very thin caps, since it can be applied on tissue as thin as $16 \mu \mathrm{m}$, as shown by Tracqui et al. (2011).

However, nano-indentation can only be performed at limited indentation depths, and may, therefore, not be able to measure at physiological strains, depending on the thickness of the tested tissue. If the measurements are only performed at low strain, the non-linear mechanical behaviour of the plaque tissue may not be captured. Measuring at small strains might lead to underestimation of the stiffness of the tissue, as the collagenous fibrous plaque tissue often displays significant strain-stiffening. This can be clearly seen in the stiffness results from the unconfined compression studies indicated in Table 1 (Maher et al., 2009, 2011; Salunke et al., 2001; Topoleski et al., 1997). In all cases, the samples are stiffer at higher strain values. On the other hand, micro-indentation

Table 1

Results of the studies treating human atherosclerotic tissue.

\begin{tabular}{|c|c|c|c|c|c|}
\hline Authors (Year) & Artery & Testing Method & Sample type & Compression & Stiffness \\
\hline \multirow[t]{3}{*}{ Lee et al. (1991) } & \multirow[t]{3}{*}{ Aorta } & \multirow[t]{3}{*}{ Unconfined compression (dynamic) } & Cellular & $17 \pm 6 \%$ & $510 \pm 220 \mathrm{kPa}$ \\
\hline & & & Hypocellular & $7 \pm 1 \%$ & $900 \pm 200 \mathrm{kPa}$ \\
\hline & & & Calcified & $1 . \overline{2} \pm 0.2 \%$ & $2.2 \pm 1.0 \mathrm{MPa}$ \\
\hline \multirow[t]{3}{*}{ Lee et al. (1992) } & \multirow[t]{3}{*}{ Aorta } & \multirow[t]{3}{*}{ Unconfined compression (static) } & Non-fibrous & $24 \pm 11 \%$ & $41 \pm 18 \mathrm{kPa}$ \\
\hline & & & Fibrous & $11 \pm 5 \%$ & $82 \pm 33 \mathrm{kPa}$ \\
\hline & & & Calcified & $3 \pm 2 \%$ & $355 \pm 245 \mathrm{kPa}$ \\
\hline Walraevens et al. (2008) & Aorta & Unconfined compression (static) & Calcified & $10 \%$ & $321 \pm 258 \mathrm{kPa}$ \\
\hline \multirow[t]{3}{*}{ Topoleski et al. (1997) } & \multirow[t]{3}{*}{ Aortoiliac } & \multirow[t]{3}{*}{ Unconfined compression (static) } & Atheromatous & $70 \pm 11 \%$ & $<10 \mathrm{kPa}$ \\
\hline & & & Fibrous & $54 \pm 9 \%$ & $<10 \mathrm{kPa}(5 \%) ; 85 \mathrm{kPa}(20 \%)$ \\
\hline & & & Calcified & $14 \pm 9 \%$ & $830 \mathrm{kPa}(5 \%) ; 13 \mathrm{MPa}(20 \%)$ \\
\hline \multirow[t]{3}{*}{ Salunke et al. (2001) } & \multirow[t]{3}{*}{ Aortoiliac } & \multirow[t]{3}{*}{ Unconfined compression (dynamic) } & Atheromatous & $25 \%$ & $25 \mathrm{kPa}(5 \%) ; 100 \mathrm{kPa}(20 \%)$ \\
\hline & & & Fibrous & $25 \%$ & $100 \mathrm{kPa}(5 \%) ; 900 \mathrm{kPa}(20 \%)$ \\
\hline & & & Calcified & $25 \%$ & 70 kPa (5\%); $1.0 \mathrm{MPa}(20 \%)$ \\
\hline \multirow[t]{3}{*}{ Maher et al. (2009) } & \multirow[t]{3}{*}{ Carotid } & \multirow[t]{3}{*}{ Unconfined compression (static) } & Echolucent & $60 \%$ & 20 kPa (5\%); 100 kPa (20\%) \\
\hline & & & Mixed & $60 \%$ & $20 \mathrm{kPa}(5 \%) ; 330 \mathrm{kPa}(20 \%)$ \\
\hline & & & Calcified & $60 \%$ & $140 \mathrm{kPa}(5 \%) ; 2.3 \mathrm{MPa}(20 \%)$ \\
\hline \multirow[t]{3}{*}{ Maher et al. (2011) } & \multirow[t]{3}{*}{ Carotid } & \multirow[t]{3}{*}{ Unconfined compression (dynamic) } & Echolucent & $10-50 \%$ & $189 \mathrm{kPa}(20 \%) 1.4 \mathrm{MPa}(50 \%)$ \\
\hline & & & Mixed & $10-50 \%$ & $105 \mathrm{kPa}(20 \%) 2.7 \mathrm{MPa}(50 \%)$ \\
\hline & & & Calcified & $10-50 \%$ & $147 \mathrm{kPa}(20 \%) 2.1 \mathrm{MPa}(50 \%)$ \\
\hline Barrett et al. (2009) & Carotid & Micro-Indentation & Fibrous cap & $5-20 \%$ & $33(21-300) \mathrm{kPa}$ \\
\hline Chai et al. (2013) & Carotid & Micro-Indentation & Intima & $30 \%$ & $30(6-891) \mathrm{kPa}$ \\
\hline \multirow[t]{4}{*}{ Ebenstein et al. (2009) } & \multirow[t]{4}{*}{ Carotid } & \multirow[t]{4}{*}{ Nano-indentation } & Haematoma & $<5 \mu \mathrm{m}$ & $230 \pm 210 \mathrm{kPa}$ \\
\hline & & & Fibrous & $<5 \mu \mathrm{m}$ & $270 \pm 150 \mathrm{kPa}$ \\
\hline & & & Calcified/fibrous & $<5 \mu \mathrm{m}$ & $2.1 \pm 5.4 \mathrm{MPa}$ \\
\hline & & & Calcified & $<5 \mu \mathrm{m}$ & $0.7 \pm 2.3 \mathrm{GPa}$ \\
\hline
\end{tabular}


experiments of Chai et al. (2013) and Barrett et al. (2009) did not show a clear non-linear behaviour, while in these studies also physiological strains were applied.

In all the studies evaluated here, a lot of variation in testing protocol can be observed (Table 2). Although the mechanical tests are preferably performed on fresh tissue, at body temperature $\left(37^{\circ} \mathrm{C}\right)$, with an appropriate preconditioning protocol, not all studies are performed under these conditions. Additionally, differences in loading protocol are apparent. Most of the studies found in literature performed static or quasi-static measurements (Barrett et al., 2009; Chai et al., 2013; Ebenstein et al., 2009; Lee et al., 1992; Maher et al., 2009; Topoleski et al., 1997; Walraevens et al., 2008), avoiding dynamic effects caused by inelasticity. Measuring at slow testing rates might allow tissue components to fully adjust to the applied loads. In other studies, dynamic loading conditions were applied to obtain inelastic and recoverability parameters (Lee et al., 1991; Maher et al., 2011; Salunke et al., 2001). High testing rates and cyclic tests with high frequencies does not allow the tissue to fully respond, possibly causing less deformation and consequently higher stiffness results. This might explain the results found by Lee et al. (1991) where the dynamic stiffness was found to be higher than the static stiffness. In general, the stiffness values between static and dynamic mechanical studies were very different. This might be, as mentioned by Lee et al. (1991), attributed to visco-elastic and poroelastic behaviour of the tissue, which may be different for different plaque components. Topoleski et al. (1997) applied quasi-static unconfined compression and obtained stiffness data ranging from
$10 \mathrm{kPa}$ (atheromatous plaques) to $13 \mathrm{MPa}$ (calcified plaques). The same group (Salunke et al., 2001) used the same set-up and obtained dynamic stiffness results ranging between $100 \mathrm{kPa}$ and $1000 \mathrm{kPa}$ (20\% compression). For atheromatous and fibrous tissue, the dynamic stiffness was higher than the static stiffness, although for calcified tissue the static results were stiffer than the dynamic results. It should be noted that the data from all studies showed a large variability. This is partly caused by the different techniques, but also by the high natural variability in mechanical behaviour of the tested samples. An accurate classification of the tissue could be beneficial for the interpretation of the results from different studies and might reduce the variability within the studies. A better classification method might, for example, be based on Fourier transform infrared spectroscopy, as previously used by Ebenstein et al. (2009). Investigating the dynamic mechanical behaviour of plaque tissue is certainly relevant since the cardiovascular system is a dynamic system which also applies hemodynamic loads on atherosclerotic plaques and causes dynamic responses of the tissue.

Due to the large variation of the stiffness results in all studies, it is impossible to draw definite conclusions on the differences in mechanical behaviour of plaques from different vascular locations. Even for plaques originating from the same vascular territory, but tested with different compression protocols, results cannot be compared directly. On average, micro-indentation results of carotid plaques (Barrett et al., 2009; Chai et al., 2013) showed much lower stiffness values than results from unconfined compression of plaques from the same territory (Maher et al., 2009), although

Table 2

Details of the studies treating human atherosclerotic tissue.

\begin{tabular}{|c|c|c|c|c|c|c|c|c|c|}
\hline $\begin{array}{l}\text { Authors } \\
\text { (Year) }\end{array}$ & Artery & $\begin{array}{l}\text { Testing } \\
\text { method }\end{array}$ & $\begin{array}{l}\text { Test } \\
\text { direction }\end{array}$ & $\begin{array}{l}\text { Number } \\
\text { of } \\
\text { patients }\end{array}$ & $\begin{array}{l}\text { Number of samples and } \\
\text { description in the study }\end{array}$ & Sample size & $\begin{array}{l}\text { Testing } \\
\text { temperature }\end{array}$ & Testing time & Preconditioning \\
\hline $\begin{array}{l}\text { Lee et al. } \\
\qquad(1991)\end{array}$ & Aorta & $\begin{array}{l}\text { Unconfined } \\
\text { Compression } \\
\text { (dynamic) }\end{array}$ & Radial & 14 & $\begin{array}{l}27 \text { fibrous caps ( } 7 \text { cellular, } \\
9 \text { hypocellular, } 11 \text { calcified) }\end{array}$ & $\begin{array}{l}\geq 4.5 \mathrm{~mm} \text { in } \\
\text { Radius }\end{array}$ & $\begin{array}{l}\text { Room } \\
\text { temperature }\end{array}$ & $\begin{array}{l}\text { Within } 16 \mathrm{~h} \text { after } \\
\text { death }\end{array}$ & $\begin{array}{l}\text { Allowed to creep } \\
\text { for } 30 \mathrm{~min}\end{array}$ \\
\hline $\begin{array}{l}\text { Lee et al. } \\
\qquad(1992)\end{array}$ & Aorta & $\begin{array}{l}\text { Unconfined } \\
\text { Compression } \\
\text { (static) }\end{array}$ & Radial & 22 & $\begin{array}{l}43 \text { atheroma caps ( } 18 \text { fibrous, } 14 \\
\text { nonfibrous, } 11 \text { calcified) }\end{array}$ & $\begin{array}{l}\geq 4.5 \mathrm{~mm} \text { in } \\
\text { Radius }\end{array}$ & $\begin{array}{l}\text { Room } \\
\text { temperature }\end{array}$ & $\mathrm{NF}$ & $\begin{array}{l}\text { Allowed to creep } \\
\text { and creep times } \\
\text { were reported. }\end{array}$ \\
\hline $\begin{array}{l}\text { Walraevens } \\
\text { et al. } \\
\text { (2008) }\end{array}$ & Aorta & $\begin{array}{l}\text { Unconfined } \\
\text { Compression } \\
\text { (static) }\end{array}$ & Radial & 19 & 19 samples & $\begin{array}{l}10 \mathrm{~mm} \times 10 \mathrm{~mm} \\
\text { Cylindrical } \\
\text { pounder } 6 \mathrm{~mm} \\
\text { diameter }\end{array}$ & $\begin{array}{l}\text { Room } \\
\text { temperature }\end{array}$ & $\begin{array}{l}\text { Within } 5 \mathrm{~h} \text { after } \\
\text { aortic repair } \\
\text { surgery }\end{array}$ & no \\
\hline $\begin{array}{l}\text { Topoleski } \\
\quad \text { et al. } \\
\text { (1997) }\end{array}$ & Aortoiliac & $\begin{array}{l}\text { Unconfined } \\
\text { Compression } \\
\text { (static) }\end{array}$ & Radial & 6 & $\begin{array}{l}24 \text { Samples from non-ulcerated } \\
\text { lesions }\end{array}$ & $\begin{array}{l}5 \mathrm{~mm} \times 5 \mathrm{~mm} \\
\text { Fixtures with } \\
6.35 \mathrm{~mm} \text { radius }\end{array}$ & $37^{\circ} \mathrm{C}$ & $\begin{array}{l}\text { Within } 12-48 \mathrm{~h} \\
\text { after death }\end{array}$ & $\begin{array}{l}\text { Repeatability } \\
\text { and } \\
\text { recoverability } \\
\text { experiments }\end{array}$ \\
\hline $\begin{array}{l}\text { Salunke } \\
\text { et al. } \\
(2001)\end{array}$ & Aortoiliac & $\begin{array}{l}\text { Unconfined } \\
\text { Compression } \\
\text { (dynamic) }\end{array}$ & Radial & NF & $\begin{array}{l}18 \text { Samples from non-ulcerated } \\
\text { lesions ( } 5 \text { calcified, } 7 \text { fibrous, } \\
6 \text { atheromatous) }\end{array}$ & $\begin{array}{l}5 \mathrm{~mm} \times 5 \mathrm{~mm} \\
\text { Plates with } \\
16 \mathrm{~mm} \text { diameter }\end{array}$ & $37^{\circ} \mathrm{C}$ & $\begin{array}{l}\text { Within } 12-48 \mathrm{~h} \\
\text { after death }\end{array}$ & $\begin{array}{l}\text { Repeatability } \\
\text { and } \\
\text { recoverability } \\
\text { experiments }\end{array}$ \\
\hline $\begin{array}{l}\text { Maher et al. } \\
\qquad(2009)\end{array}$ & Carotid & $\begin{array}{l}\text { Unconfined } \\
\text { Compression } \\
\text { (static) }\end{array}$ & Radial & 11 & $\begin{array}{l}44 \text { Plaque samples ( } 16 \text { calcified, } \\
5 \text { echolucent, } 23 \text { mixed) }\end{array}$ & $\begin{array}{l}4 \mathrm{~mm} \text { in } \\
\text { Diameter }\end{array}$ & NF & $\begin{array}{l}\text { Within } 2 \mathrm{~h} \text { after } \\
\text { endarterectomy }\end{array}$ & $\begin{array}{l}10 \text { Times up to } \\
10 \% \text { strain }\end{array}$ \\
\hline $\begin{array}{l}\text { Maher et al. } \\
\qquad(2011)\end{array}$ & Carotid & $\begin{array}{l}\text { Unconfined } \\
\text { Compression } \\
\text { (dynamic) }\end{array}$ & Radial & 8 & $\begin{array}{l}21 \text { Plaque samples ( } 8 \text { calcified, } \\
5 \text { echolucent, } 8 \text { mixed) }\end{array}$ & $\begin{array}{l}4 \mathrm{~mm} \text { in } \\
\text { Diameter }\end{array}$ & $\begin{array}{l}\text { Room } \\
\text { temperature }\end{array}$ & $\begin{array}{l}\text { Within } 2 \mathrm{~h} \text { after } \\
\text { endarterectomy }\end{array}$ & $\begin{array}{l}\text { Repeatability } \\
\text { and } \\
\text { recoverability } \\
\text { experiments }\end{array}$ \\
\hline $\begin{array}{c}\text { Barrett et al. } \\
\text { (2009) }\end{array}$ & Carotid & $\begin{array}{l}\text { Micro- } \\
\text { Indentation }\end{array}$ & Radial & 8 & 8 plaques & $\begin{array}{l}\text { Indenter radius } \\
0.5 \mathrm{~mm}\end{array}$ & NF & $\begin{array}{l}\text { Within } 3 \mathrm{~h} \text { after } \\
\text { endarterectomy }\end{array}$ & $\mathrm{NF}$ \\
\hline $\begin{array}{l}\text { Chai et al. } \\
\text { (2013) }\end{array}$ & Carotid & $\begin{array}{l}\text { Micro- } \\
\text { Indentation }\end{array}$ & Axial & 8 & $\begin{array}{l}\text { 6-13 Slices per plaque, } 214 \\
\text { locations in total ( } 43 \text { fibrous } \\
\text { cap, } 61 \text { plaque shoulder, } 90 \\
\text { intima, } 20 \text { necrotic core) }\end{array}$ & $\begin{array}{l}\text { Indenter radius } \\
1 \mathrm{~mm}\end{array}$ & $\begin{array}{l}\text { Room } \\
\text { temperature }\end{array}$ & $\begin{array}{l}\text { Snapfrozen } \\
\text { directly after } \\
\text { endarterectomy } \\
\text { Storage time } \\
\text { unknown }\end{array}$ & $\begin{array}{l}2 \\
\text { Preconditioning } \\
\text { cycles }\end{array}$ \\
\hline $\begin{array}{l}\text { Ebenstein } \\
\quad \text { et al. } \\
\text { (2009) }\end{array}$ & Carotid & $\begin{array}{l}\text { Nano- } \\
\text { indentation }\end{array}$ & Radial & 10 & $\begin{array}{l}377 \text { Locations ( } 34 \text { hematoma, } \\
172 \text { fibrous, } 72 \text { partially } \\
\text { calcified, } 99 \text { calcified locations) }\end{array}$ & $\begin{array}{l}\text { Conospherical } \\
\text { indenter } \\
\text { diameter } \\
200 \mu \mathrm{m}\end{array}$ & $\begin{array}{l}\text { Room } \\
\text { temperature }\end{array}$ & $\begin{array}{l}5 \text { Samples stored } \\
\text { at }-20{ }^{\circ} \mathrm{C} \\
5 \text { Samples fresh } \\
<24 \mathrm{~h}\end{array}$ & NF \\
\hline
\end{tabular}

NF: not found. 
overlap exists in the testing results. If unconfined compression tests are dominated by relative stiff inclusions in the tested tissue, this may explain why the local micro-indentation tests results in lower stiffness values on average, with values closer to the unconfined compression stiffness values for calcified inclusions. Since differences in testing approach also leads to differences in mechanical stiffness results, it is important to put the results from these studies in the correct perspective. The application (multiscale modelling, macroscopic plaque modelling, and stiffness comparison for different plaque types or location) should determine which type of testing system and protocol is most applicable.

In the reviewed experimental studies, the most occurring compression direction is radial, except for Chai et al. (2013), where the compression direction was axial. Indentation in the radial direction is a more physiologically relevant loading condition, as plaque tissue is mostly compressed in this direction and stretched circumferentially. The expected anisotropy of the tissue suggests that testing the stiffness of plaque tissue in different directions will lead to different results (Holzapfel et al., 2004). However, in Chai et al. (2013) a small set of longitudinal samples was also tested and the circumferential compressive stiffness results were comparable to the axial results.

A major limitation of the three presented measurements techniques is the fact that only isotropic behaviour can be determined from the measurement data. Given the high collagen fibre content and alignment in the plaque, the assumption of isotropic behaviour is likely not valid. In the next section, a method based on micro-indentation is presented that can be applied to determine anisotropic material behaviour of atherosclerotic plaque tissue.

\section{Local anisotropic behaviour of human carotid plaques}

In this section, an in-house developed micro-indentation test setup (Vaenkatesan et al., 2006) is introduced that can be used to perform mechanical testing on soft tissue and allows the analysis of the anisotropic mechanical behaviour (Cox et al., 2008). With this set-up, anisotropic material properties were previously derived of tissue-engineered constructs, tissue engineered heart valves, and bio-artificial muscle tissue (Cox et al., 2006, 2008, 2010). The testing method will be illustrated with data from a single atherosclerotic carotid plaque sample, which was obtained during carotid endarterectomy.

\subsection{Sample preparation}

After carotid endarterectomy, the sample was snap-frozen in liquid nitrogen and stored at a temperature of $-80^{\circ} \mathrm{C}$. In a later stage, the frozen sample was axially sliced using a cryotome at $-20{ }^{\circ} \mathrm{C}$, to obtain $200 \mu \mathrm{m}$ thick sections at $1 \mathrm{~mm}$ intervals (Fig. 1). Prior to the indentation tests, the sections were thawed and a fluorescent collagen staining (CNA-35; Nash-Krahn et al., 2006) was applied overnight at $4{ }^{\circ} \mathrm{C}$. Approval was given by the local institutional review board and informed consent was obtained from the patient. A more detailed description of the sample preparation can be found in Chai et al. (2013).

\subsection{Micro-indentation test}

For the mechanical testing, the section of the plaque was placed under the micro-indentation setup. The micro-indentation was performed in the axial direction of the vessel using a sapphire spherical indenter with a diameter of $2 \mathrm{~mm}$. The indenter was placed above an inverted confocal microscope to visualise the collagen deformation during indentation in the bottom plane of the section. During the indentation experiment, the force-response, indentation depth and collagen deformation were recorded. Digital image correlation (DIC) was applied on the collagen deformation images using commercially available software (ARAMIS, GmbH, Germany) to obtain the local displacement field during indentation. From the displacement field, the local deformations and principal strain directions were determined. The displacements, local first $\left(\varepsilon_{\boldsymbol{x}}\right)$ and second $\left(\varepsilon_{\boldsymbol{y}}\right)$ principal strain magnitude and direction of the collagen fibres were quantified as function of the indentation depth (Fig. 2). The fibre displacement versus the global stress clearly illustrates the anisotropic behaviour of the plaque (Fig. 3). The tissue offers much more resistance in the direction of the fibre alignment whereas perpendicular to the fibre direction much higher strain occurred during indentation. More details on the testing protocol can be found in Chai et al. (2013).

The force-response, the indentation depth, and the quantified collagen deformation were used as input for an inverse finite element analysis to determine the in-plane anisotropic behaviour of the tested tissue.

\subsection{Inverse finite element analysis}

To represent the indentation test setup for the inverse finite element analysis (FEA), a three-dimensional computational model

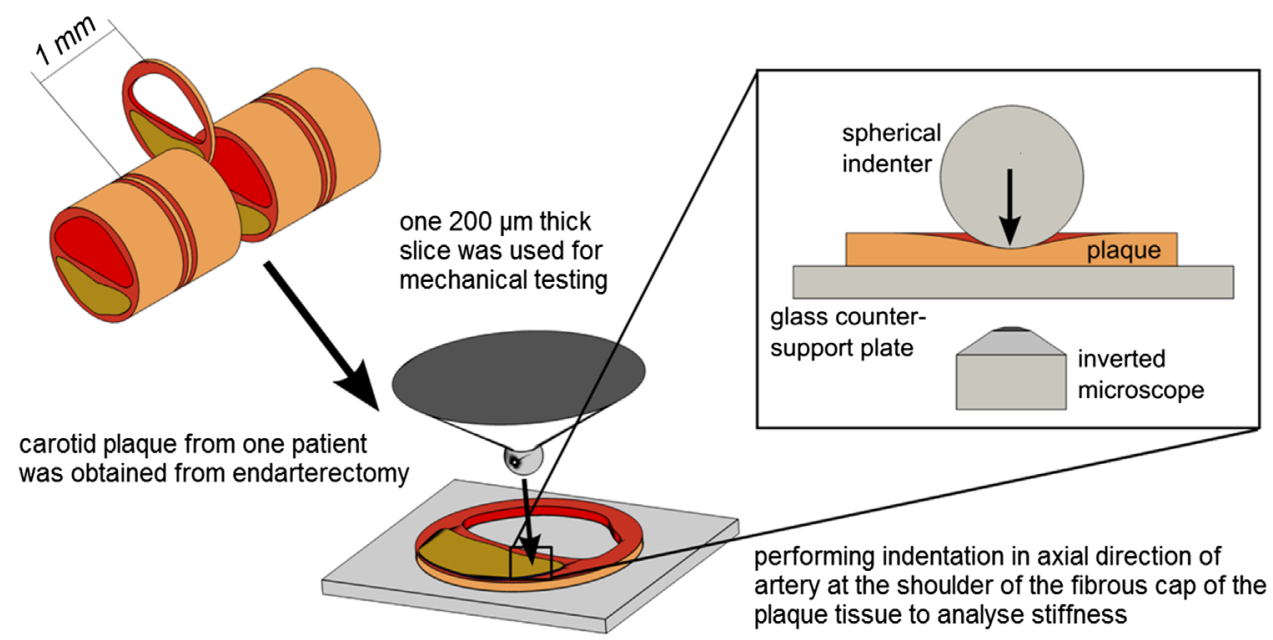

Fig. 1. Sectioning of plaque tissue with a cryotome to create a $200 \mu \mathrm{m}$ thick slice for mechanical testing.

Reprinted from Chai et al. (2013), Copyright (2013), with permission from Elsevier. 


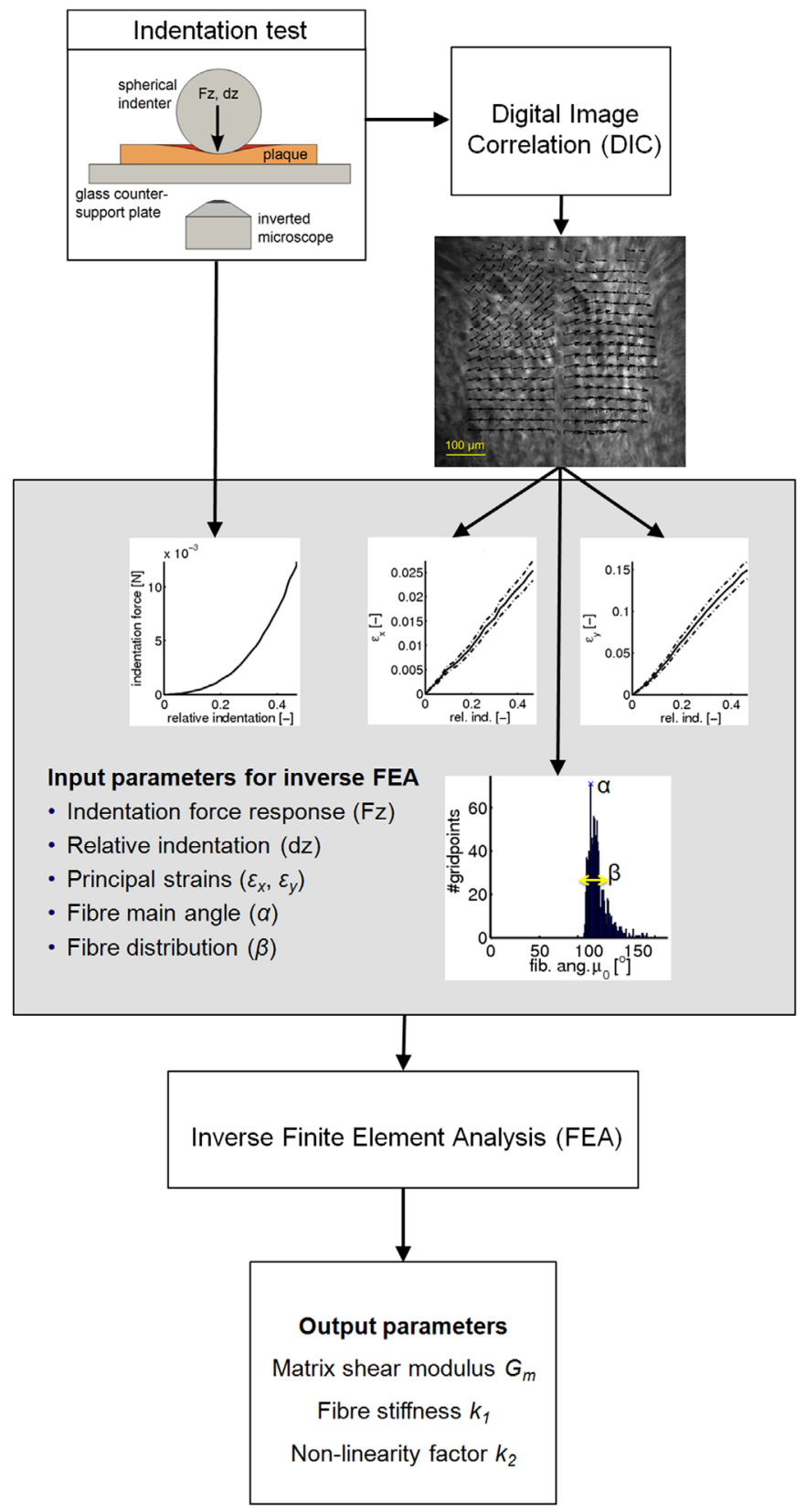

Fig. 2. Flowchart depicting the input and output parameters of the inverse finite element analysis. From the indentation experiment the force-depth curves were obtained. Confocal imaging of the collagen structure of atherosclerotic plaque tissue during indentation allows digital image correlation (black arrows indicate the deformation) to derive the principal strains. From the confocal images also the fibre main angle and fibre dispersion were obtained. This data was used as input for the inverse FEA to infer matrix shear modulus $G_{m}$, fibre stiffness $k_{1}$, and nonlinearity factor $k_{2}$.

was generated (Fig. 2). An anisotropic material model, proposed by Driessen et al. (2008), was applied for the atherosclerotic tissue

$\tau=\tau_{m}+\tau_{f}=G_{m}\left(\boldsymbol{F} \boldsymbol{F}^{T}-\boldsymbol{I}\right)+\sum_{i=1}^{N_{f}} \phi_{f}^{i}\left[\Psi_{f}^{i}-\vec{e}_{f}^{i} \tau_{m} \vec{e}_{f}^{i}\right] \vec{e}_{f}^{i} \vec{e}_{f}^{i}$

here the local collagen structure of the atherosclerotic plaque is described by splitting the extra stress tensor $\tau$ into an isotropic matrix part $\tau_{m}$ and an anisotropic fibre part $\tau_{f}$. The extracellular matrix is characterised by $\tau_{m}$ and modelled as an incompressible neo-Hookean material, with matrix shear modulus $G_{m}$. $\boldsymbol{F}$ is the deformation tensor and $\boldsymbol{I}$ the unity tensor. The anisotropic part $\tau_{f}$

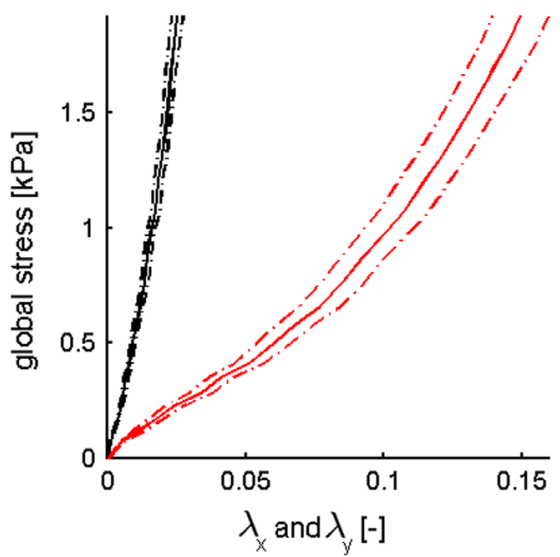

Fig. 3. The diagram shows the global stress against the collagen fibre displacement: $\lambda_{x}$ fibre stretch: $\lambda_{y}$ displacement perpendicular to fibre alignment. It shows again highly anisotropic behaviour of the tissue. The resistance in the direction of the fibres is much higher, whereas much higher strain appears perpendicular to the fibre direction.

represents the collagen fibres in the tissue with $\vec{e}_{f}$ the current fibre direction, $\psi_{f}$ the fibre stress, and $N_{f}$ the discrete number of fibres. The volume fraction of fibres $\phi_{f}^{i}$ is modelled with a periodic Gaussian distribution, as shown in the following equation:

$\phi_{f}^{i}\left(\gamma_{i}\right)=A \exp \frac{\cos \left[2\left(\gamma_{i}-\alpha\right)\right]+1}{\beta}$

here $\gamma_{i}$ is the fibre angle and $A$ the scaling factor to make sure that $\phi_{\text {tot }}=1$. The main fibre direction is $\alpha$, and $\beta$ is the fibre distribution, both parameters $\alpha$ and $\beta$ are derived from the confocal images (Fig. 2). In our test sample, the main fibre direction $\alpha$ was $101^{\circ}$, which is close to a circumferential orientation. The fibre distribution $\beta$ was 0.7 indicating a rather anisotropic distribution, which matches with the image in Fig. 2.

The fibre stress $\psi_{f}$ was modelled based on Holzapfel et al. (2000), where $\psi_{f}$ was described as a function of the fibre stretch $\lambda_{f}$, the fibre stiffness $k_{1}$ and the non-linearity factor $k_{2}$.

$\Psi_{f}^{i}=2 k_{1} \lambda_{f}^{2}\left(\lambda_{f}^{2}-1\right) \exp \left(k_{2}\left(\lambda_{f}^{2}-1\right)^{2}\right)$

The fibre stretch $\lambda_{f}$ is derived from the digital image correlation (DIC), while $k_{1}$ and $k_{2}$ are output parameters from the inverse FEA, together with the matrix shear modulus $G_{m}$. For the inverse FEA, an iterative mixed experimental-computational approach based on the method by Cox et al. (2006) and Meuwissen et al. (1998) was applied. The difference between experimental measurements and the simulated data obtained from the FEA was minimised by applying a Gaussian-Newton minimisation algorithm. For our test sample, the matrix stiffness $G_{m}$ reached the lower limit of $1.0 \mathrm{kPa}$, while the fibre stiffness $k_{1}$ was determined as $16.3 \mathrm{kPa}$. The nonlinearity factor $k_{2}$ was 0.8 . The tested sample showed a very anisotropic material (Fig. 3) with a non-linear behaviour and a relative low fibre stiffness, compared to reported values (Table 1 ). Future anisotropic characterisation of plaque tissue will provide insight in the values and variation of the mechanical properties of human atherosclerotic tissue. For more information on the DIC and inverse finite element analysis, see Cox et al. (2006, 2008).

Fig. 4 shows the experimental and simulated data for our test sample with the optimal material parameters. The simulated data corresponded very well to the experimental data, indicating that the proposed material model accurately describes the mechanical behaviour of the tested tissue. Future studies will show if this material model also appropriately characterises atherosclerotic plaque tissue in general. 

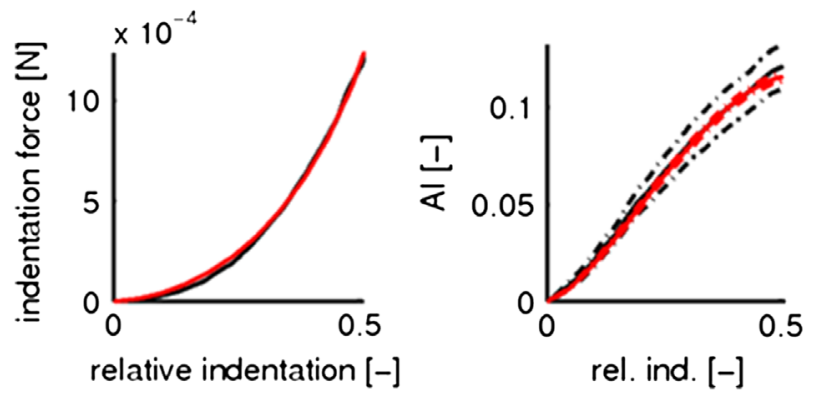

$$
A I=\frac{\lambda_{y}}{\lambda_{x}}-1
$$

- Experimental data

- Simulated data

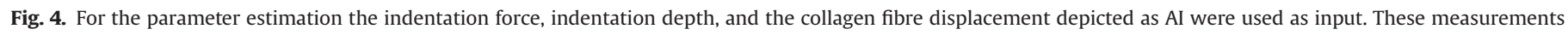
were fitted to the simulated data from the FE simulations.

\subsection{Discussion}

The combination of an indentation test with a confocal microscope does not only enable the measurement of indentation force and depth, but also the visualisation of collagen fibre deformation, perpendicular to the indentation direction. From this, anisotropic mechanical data can be extracted that is representative for the extensional properties in the plane perpendicular to the indentation direction at finite strains. Information on anisotropic material parameters may improve the accuracy and reliability of biomechanical plaque models and, additionally, the risk assessment of plaque rupture.

In this paper, material parameters of a single atherosclerotic carotid plaque sample were presented, revealing highly anisotropic mechanical behaviour of the plaque. Confocal microscopy confirmed a high alignment of collagen fibres. The global stressstrain behaviour showed that the highest strain occurred perpendicular to the main fibre direction and that tissue stretch in the fibre direction was much smaller. More atherosclerotic plaque samples need to be tested to fully evaluate the anisotropic mechanical behaviour of carotid plaque tissue.

In the in vivo situation, the blood vessel experiences global blood pressure in the radial direction, with circumferential (and axial) stretching and radial compression of the vessel wall. The used indentation technique applies a local compressive force in axial direction, resulting in local circumferential and radial stretching of the tissue. Computer simulations have shown that the level of circumferential stretch in this study corresponds to the level of stretch in the physiological situation. As the collagen fibres are the major load-bearing structures in the wall, mainly oriented in the circumferential direction, the indentation technique evaluates the mechanical properties of the collagen fibres in the most relevant direction. Additionally, by testing relatively thin slices in axial direction it was strived to test a slice of homogeneous material over the thickness. Also, these thin slices enable the assumption of a uniform fibre distribution throughout the slice thickness, required for the inverse finite element analysis. On the other hand, the slicing may also disrupt the coherence in the collagen fibre architecture. Since the collagen fibres are the load-bearing structure of the blood vessel, this might have an impact on the mechanical properties.

Another factor that can affect the collagen structure is the axial in vivo pre-stretch. On average, arteries are under $30 \%$ pre-stretch (Schulze-Bauer et al., 2003; Humphrey et al., 2009; van der Horst et al., 2012), likely resulting in a more axial collagen distribution than the stretch free samples tested with the indentation test. This altered collagen distribution may have an effect on the macroscopic stiffness results as determined with the inverse finite element analysis. Accounting for the axial pre-stretch in the inverse finite element analysis may give more insight in the effect of this pre-stretch on the mechanical behaviour of the tissue.

The studied plaque tissue was frozen and stored due to logistical reasons. The collagen fibres might be damaged due to the freezing process. However, ice-crystal formation was minimised by snap-freezing the tissue in liquid nitrogen after endarterectomy. The confocal images, histological images, and light microscopy evaluation did not show any tissue damage due to ice-crystal formation. Additionally, Ebenstein et al. (2009) concluded that there were no differences in mechanical behaviour between fresh and frozen plaque samples.

\section{Main conclusions}

Mechanical testing of atherosclerotic plaque tissue involves several difficulties. Depending on the required information, more global or local measurements can be applied. Global mechanical properties of plaque tissue have been characterised using unconfined compression, tensile, or inflation tests. These tests rely on (intact) blood vessels with a significant size. However, atherosclerotic plaque tissue is often only available in small samples, insufficient for a proper handling and testing. Testing small-sized plaques with compression, inflation, biaxial, or uni-axial tensile tests is rather difficult. Additionally, since plaque tissue is heterogeneous, consisting of different components, it can be assumed that its mechanical properties are also heterogeneous. Tests using a smaller sized indenter allow a more local measurement, therefore, avoiding the tissue size problem. Nano-indentation tests allow very local measurements. However, the found studies applying small micro-meter indenter tips could only test plaque tissue at small strains. To characterise the mechanical properties of plaque tissue, it is crucial that mechanical testing is done at physiological strain. Using micro-indentation, local force-indentation measurements can be performed on relative homogeneous tissue at physiological relevant strain values. As shown in this review, micro-indentation may also be used to identify anisotropic material behaviour of plaque tissue. In conclusion, compressive mechanical properties of atherosclerotic plaques can be determined using unconfined compression (global and dynamic properties), micro-indentation (local properties) or nano-indentation (micro level properties). Depending on the desired information, one of these techniques can be used and the advantages and disadvantages can be found in this review.

\section{Conflict of interest statement}

We declare that there are no issues that may be considered as potential conflicts of interest to this work.

\section{Acknowledgement}

This research was supported by the Centre for Translational Molecular Medicine and the Dutch Heart Foundation (PARISk). The assistance of Dr. Frank J.H. Gijsen, Mr. Ali C. Akyildiz, and colleagues at the Erasmus Medical Centre is gratefully acknowledged. 


\section{References}

Ali C. Akyildiz, Lambert Speelman, Frank J.H. Gijsen, Mechanical properties of human atherosclerotic intima tissue, J. Biomech. Available online 14 January 2014, ISSN 0021-9290, http://dx.doi.org/10.1016/j.jbiomech.2014.01.019, this issue (http://www. sciencedirect.com/science/article/pii/S0021929014000487).

Akyildiz, A.C., Speelman, L., van Brummelen, H., Gutiérrez, M.A., Virmani, R., van der Lugt, A., van der Steen, A.F.W., Wentzel, J.J., Gijsen, F.J.H., 2011. Effects of intima stiffness and plaque morphology on peak cap stress. BioMed. Eng. Online 10 (25), 1-13.

Barrett, S.R.H., Sutcliffe, M.P.F., Howarth, S., Li, Z.-Y., Gillard, J.H., 2009. Experimental measurement of the mechanical properties of carotid atherothrombotic plaque fibrous cap. J. Biomech. 42, 1650-1655.

Chai, C.-K., Akyildiz, A.C., Speelman, L., Gijsen, F.J.H., Oomens, C.W.J., van Sambeek, M.R.H.M., van der Lugt, A., Baaijens, F.P.T., 2013. Local axial compressive mechanical properties of human carotid atherosclerotic plaques-characterisation by indentation test and inverse finite element analysis. J. Biomech. 46 (10), 1759-1766.

Cox, M.A.J., Driessen, N.J.B., Boerbom, R.A., Bouten, C.V.C., Baaijens, F.P.T., 2008. Mechanical characterization of anisotropic planar biological soft tissues using finite indentation: experimental feasibility. J. Biomech. 41, 422-429.

Cox, M.A.J., Driessen, N.J.B., Bouten, C.V.C., Baaijens, F.P.T., 2006. Mechanical characterization of anisotropic planar biological soft tissues using large indentation: a computational feasibility study. J. Biomech. Eng. 128, 428-436.

Cox, M.A.J., Kortsmit, J., Driessen, N., Bouten, C.V.C., Baaijens, F.P.T., 2010. Tissueengineered heart valves develop native-like collagen fiber architecture. Tissue Eng.: Part A 16 (5), 1527-1537.

Driessen, N.J.B., Cox, M.A.J., Bouten, C.V.C., Baaijens, F.P.T., 2008. Remodeling of the angular collagen fiber distribution in cardiovascular tissues. Biomech. Model. Mechanobiol. 7, 93-103.

Ebenstein, D.M., Coughlin, D., Chapman, J., Li, C., Pruitt, L.A., 2009. Nanomechanical properties of calcification, fibrous tissue, and hematoma from atherosclerotic plaques. Wiley Periodicals, Inc. J. Biomed. Mater. Res. 91A, 1028-1037.

Gillard, J.H., 2007. Advances in atheroma imaging in the carotid. Cerebrovasc. Dis. $24,40-48$.

Hayenga, H.N., Trache, A., Trzeciakowski, J., Humphrey, J.D., 2011. Regional atherosclerotic plaque properties in ApoE-/- mice quantified by atomic force, immunofluorescence, and light microscopy. J. Vasc. Res. 48, 495-504.

Holzapfel, G.A., Gasser, T.C., Ogden, R.W., 2000. A new constitutive framework for arterial wall mechanics and a comparative study of material models. J. Elast. 61 (1-3), 1-48.

Holzapfel, G.A., Sommer, G., Regitnig, P., 2004. Anisotropic mechanical properties of tissue components in human atherosclerotic plaques. J. Biomech. Eng. 126, 657-665.

Humphrey, J.D., Eberth, J.F., Dye, W.W., Gleason, R.L., 2009. Fundamental role of axial stress in compensatory adaptations by arteries. J. Biomech. 42, 1-8.

Kolodgie, F.D., Burke, A.P., Farb, A., Gold, H.K., Yuan, J., Narula, J., Finn, A.V., Virmani, R., 2001. The thin-cap fibroatheroma: a type of vulnerable plaque. The major precursor lesion to acute coronary syndromes. Curr. Opin. Cardiol. 16, 285-292.

Lawlor, M.G., O’Donnell, M.R., O’Donnell, B.M., Walsh, M.T., 2011. Experimental determination of circumferential properties of fresh carotid artery plaques. J. Biomech. 44 (9), 1709-1715.

Lee, R.T., Grodzinsky, A.J., Frank, E.H., Kamm, R.D., Schoen, F.J., 1991. Structuredependent dynamic mechanical behavior of fibrous caps from human atherosclerotic plaques. Circulation 83 (5), 1764-1770.

Lee, R.T., Richardson, S.G., Loree, H.M., Grodzinsky, A.J., Gharib, S.A., Schoen, F.J., Pandian, N., 1992. Prediction of mechanical properties of human atherosclerotic tissue by high-frequency intravascular ultrasound imaging an in vitro study. Arterioscler. Thromb. Vasc. Biol. 12, 1-5.

Loree, H.M., Kamm, R.D., Stringfellow, R.G., Lee, R.T., 1992. Effects of fibrous cap thickness on peak circumferential stress in model atherosclerotic vessels. Circ. Res. 71, 850-858.

Loree, H.M., Tobias, B.J., Gibson, L.J., Kamm, R.D., Small, D.M., Lee, R.T., 1994. Mechanical properties of model atherosclerotic lesion lipid pools. Arterioscler. Thromb. Vasc. Biol. 14, 230-234.

Maher, E., Creane, A., Sultan, S., Hynes, N., Lally, C., Kelly, D.J., 2009. Tensile and compressive properties of fresh human carotid atherosclerotic plaques. J. Biomech. 42, 2760-2767.

Maher, E., Creane, A., Sultan, S., Hynes, N., Lally, C., Kelly, D.J., 2011. Inelasticity of human carotid atherosclerotic plaque. Ann. Biomed. Eng. 39 (9), 2445-2455.

Meuwissen, M.H.H., Oomens, C.W.J., Baaijens, F.P.T., Petterson, R., Janssen, J.D., 1998. Determination of the elasto-plastic properties of aluminium using a mixed numerical-experimental method. J. Mater. Process. Technol. 75, 204-211.

Naghavi, M., 2010. Asymptomatic Atherosclerosis-Pathophysiology, Detection and Treatment. Society for Heart Attack Prevention and Eradication (SHAPE).
Humana Press, Springer New York Dordrecht Heidelberg London, http://dx. doi.org/10.1007/978-1-60327-179-0.

Nash-Krahn, K., Bouten, C.V.C., van Tuijl, S., van Zandvoort, M.A.M.J., Merkx, M. 2006. Fluorescently labeled collagen binding proteins allow specific visualization of collagen in tissues and live cell culture. Anal. Biochem. 350, 177-185.

Nieuwstadt, H.A., Geraedts, T.R., Truijman, M.T.B., Kooi, M.E., van der Lugt, A., van der Steen, A.F.W., Wentzel, J.J., Breeuwer, M., Gijsen, F.J.H., Numerical simulations of carotid MRI quantify the accuracy in measuring atherosclerotic plaque components in vivo. Magn. Reson. Med. http://dx.doi.org/10.1002/mrm.24905, in press.

Redgrave, J.N., Gallagher, P., Lovett, J.K., Rothwell, P.M., 2008. Critical cap thickness and rupture in symptomatic carotid plaques. The Oxford Plaque Study. Stroke 39 (6), 1722-1729.

Sadat, U., Teng, Z., Young, V.E., Li, Z.Y., Gillard, J.H., 2011. Utility of magnetic resonance imaging-based finite element analysis for the biomechanical stress analysis of hemorrhagic and nonhemorrhagic carotid plaques. Circ. J. 75 884-889.

Sakakura, K., Nakano, M., Otsuka, F., Ladich, E., Kolodgie, F.D., Virmani, R., 2013. Pathophysiology of atherosclerosis plaque progression. Heart, Lung Circ. 22 399-411.

Salunke, N.V., Topoleski, L.D.T., Humphrey, J.D., Mergner, W.J., 2001. Compressive stress-relaxation of human atherosclerotic plaque. J. Biomed. Mater. Res. 55 236-241.

Salunke, N.V., Topoleski, L.D.T., 1997. Biomechanics of atherosclerotic plaque. Crit. Rev. Biomed. Eng. 25 (3), 243-285.

Schaar, J.A., Muller, J.E., Falk, E., Virmani, R., Fuster, V., Serruys, P.W., Colombo, A., Stefanadis, C., Ward Casscells, S., Moreno, P.R., Maseri, A., van der Steen, A.F.W. 2004. Terminology for high-risk and vulnerable coronary artery plaques. Eur. Heart J. 25, 1077-1082.

Schulze-Bauer, C.A.J., Mörth, C., Holzapfel, G.A., 2003. Passive biaxial mechanical response of aged human iliac arteries. J. Biomech. Eng. 125, 395-406.

Speelman, L., Akyilidz, A.C., den Adel, B., Wentzel, J.J., van der Steen, A.F.W., Virmani, R., van der Weerd, L., Jukema, J.W., Poelmann, R.E., van Brummelen, E.H., Gijsen, F.J.H., 2011. Initial stress in biomechanical models of atherosclerotic plaques. J. Biomech. 44, 2376-2382.

Stary, H.C., Blankenhorn, D.H., Chandler, A.B., Glagov, S., Insull , W., Richardson, M., Rosenfeld, M.E., Schaffer, S.A., Schwartz, C.J., Wagner, W.D., et al., 1992 A definition of the intima of human arteries and of its atherosclerosis-prone regions. A report from the Committee on Vascular Lesions of the Council on Arteriosclerosis. American Heart Association. Circulation, 85; , pp. 391-405.

Tang, D., Teng Z, Canton, G., Hatsukami, T.S., Dong, L., Huang, X, Yuan, C, 2009. Local critical stress correlates better than global maximum stress with plaque morphological features linked to atherosclerotic plaque vulnerability: an in vivo multi-patient study. BioMed. Eng. Online 8 (15), http://dx.doi.org/ 10.1186/1475-925X-8-15.

Tang, D., Yang, C., Zheng, J., Woodrad, P.K., Saffiz, J.E., Sicard, G.A., Pilgram, T.K., Yuan, C., 2005. Quantifying effects of plaque structure and material properties on stress distributions in human atherosclerotic plaques using 3D FSI models. J. Biomech. Eng. 127 (7), 1185-1194.

Topoleski, L.D.T., Salunke, N.V., Humphrey, J.D., Mergner, W.J., 1997. Compositionand history-dependent radial compressive behavior of human atherosclerotic plaque. J. Biomed. Mater. Res. 35, 117-127.

Topoleski, L.D.T. Salunke, N.V., 2000. Mechanical behavior of calcified plaques: summary of compression and stress-relaxation experiments. Z. Kardiol. 89 (Suppl. 2), II/85-II/91.

Tracqui, P., Broisat, A., Toczek, J., Mesnier, N., Ohayon, J., Riou, L., 2011. Mapping elasticity moduli of atherosclerotic plaque in situ via atomic force microscopy. J. Struct. Biol. 174 (1), 115-123.

Vaenkatesan, V., Li, Z.L., Vellinga, W.P., 2006. Adhesion and friction behaviours of polydimethylsiloxane-a fresh perspective on JKR measurements. Polymer 47 (25), 8317-8325.

van der Horst, A., van den Broek, C.N., van de Vosse, F.N., Rutten, M.C.M., 2012. The fiber orientation in the coronary arterial wall at physiological loading evaluated with a two-fiber constitutive model. Biomech. Model. Mechanobiol. 11, 533-542.

Walraevens, J., Willaert, B., De Win, G., Ranftl, A., De Schutter, J., Vander Sloten, J. 2008. Correlation between compression, tensile and tearing tests on healthy and calcified aortic tissues. Med. Eng. Phys. 30, 1098-1104.

Walsh, M.T., Cunnane, E.M., Mulvihill, J.J., Akyildiz, A.C., Gijsen, F.J.H., Holzapfel, G.A., 2013. Uniaxial tensile approaches for characterization of atherosclerotic plaques. J. Biomech., http://dx.doi.org/10.1016/j.jbiomech.2014.01.017, this issue.

Williamson, S.D., Lam, Y., Younis, H.F., Huang, H., Patel, S., Kaazempur-Mofrad, M.R., Kamm, R.D., 2003. On the sensitivity of wall stresses in diseased arteries to variable material properties. J. Biomech. Eng. 125, 147-155. 